\title{
THE TRANSNATIONAL STATE, NEOLIBERALISM AND ENVIRONM ENTAL EDUCATION POLICY: A NEW ZEALAND CASE STUDY
}

\author{
LYNLEY TULLOCH \\ lynleyt@waikato.ac.nz \\ The University of Waikato
}

\begin{abstract}
The neoliberalisation of environmental policy (including environmental education) is complex and multifaceted and one in which the transnational state (TNS) is central. In order to address this claim, the first part of this paper explains the transnational state and in particular the role of the UN in redefining sustainable development and environmental education. I show how underpinning this process is the nation states "transmission belt" function in which global policy directives are transmitted to the local level. This is achieved through a discussion of the dissemination of neoliberalized sustainable development policy in New Zealand policy contexts. I demonstrate this process by identifying policy formation located at different points in this process, and then via an analysis of its specific form in the context of EE in New Zealand educational settings. The paper then considers the neoliberal substance of this sustainable development led EE discourse in New Zealand which is linked both with its anthropocentric orientation, and its "problem solving," soft-green managerialist/technological approach to the environment.
\end{abstract}

Keywords: neoliberalism; environmental education; transnational state; human-nature relations; ideology; curriculum policy

How to cite: Tulloch, Lynley (2016), "The Transnational State, Neoliberalism and Environmental Education Policy: A New Zealand Case Study," Contemporary Readings in Law and Social Justice 8(2): 170-195.

Received 20 March 2016• Received in revised form 1 April 2016 Accepted 2 April 2016• Available online 20 April 2016 


\section{Introduction}

Sustainable development (SD) originated in third world politics and is based on radical deep green and red-green (Marxist) environmental thought (Carruthers, 2005; Tulloch \& Neilson, 2014). However, SD has been wrenched from its location in radical anti-globalization third world politics and redefined through a series of international summits as part of a broader developmental agenda. It promises to address a multitude of problems including environmental degradation, uneven development, poverty, disempowerment of indigenous peoples, and war. While there are diverse interpretations of SD, the dominant reading is that which has been shaped by Agenda 21 (United Nations Conference on Environment and Development (UNCED), 1992). Agenda 21 was the document that arose from the 1992 Rio de Janeiro (UNCED), 1992) conference (also called the Earth Summit). Paradoxically, the economic agenda underpinning Agenda 21 is based on the expansion of global markets and insists on continued economic growth (Doyle, 1998). The integration of environmental concerns with economic and social aspects has been critiqued at various levels, not least of which is the push for redesigning the economy in line with neoliberal logic and free market globalization (Tulloch \& Neilson, 2014).

The United Nations (UN) has been particularly instrumental in the development of Sustainable Development Discourse (SDD), and its dissemination in policy at various levels from global through to local. In its current form, SDD stresses the integration of social and economic global capitalist development goals with environmental concerns. Sustainable development discourse (SDD) is now a neoliberalized explanatory framework by which all dominant forms of environmental discourse are produced and reproduced (Dryzek, 2005). It applies neoliberal principles of privatization, commodification and marketization to the environment, broadly conceived in anthropocentric terms as natural resources and ecosystem services.

The anti-capitalist agenda and "limits-to-growth" logic of earlier SD proponents originating in third world politics of the 1970s has been pushed to the margins by this pro-neoliberal reworking of the concept. The primary focus is now on decontextualized behaviors and values of individuals and social groups. People's values and behaviors are, of course, important in the transition to a genuinely sustainable world. This is why environmental education (EE) and education for sustainability (EfS) both stress citizenship education involving values development and advocate for intergenerational behavioral change. However, this paper argues that SDD fails to address two important points: a) the historical materialist dialectic between the capitalist economy and the formation of particular behavioral and value orientations and b) an analysis of the genesis of environmental/social and economic 
crises as lying within globalized neoliberal capitalism itself. Conversely, the neoliberal goals of economic growth and open markets have been promoted since the Rio Summit in 1992 as the solution to rather than the cause of our environmental crisis (Tulloch \& Neilson, 2014).

It should be evident from the above discussion that an analysis of local EE policy needs to be situated within a critical understanding of its embeddedness in wider global processes of capitalist expansion. Thus, the neo-Gramscian perspective of this paper considers the emergence of SDD in relation to a historically specific configuration of the capitalism-state-society complex (Cox, 1981). The current age of globalization of capital is integrally connected with the transnationalization of the state (Robinson, 2001). Accordingly, the state is not a form of immutable geo-political dynamics or in Weberian terms a "relatively independent national actor driven by geo-political competition with other states" (Robinson, 2001, p. 190). Rather, boundaries are transcended as a new economic order of global rather than national circuits of accumulation emerges. The structure of the state has altered alongside the economic changes and is linked with the rise of transnational state (TNS) bureaucracies that seek to supersede and incorporate the national state and redefine the nature of the social order.

The dissemination of neoliberalized SDD from (in this case) the UN to policy formation in New Zealand is not a simple reproduction (although it can appear in some instances to uplift many ideas that appear almost verbatim). Nonetheless, the way in which the neoliberal ideas/policy mechanisms are articulated means that each nation has its own version. As the global discourse goes through this process it comes in contact with a local context and discourses. The relay of ideas involves engagement with New Zealand as a local context resulting in a particular New Zealand variety.

This process can be understood more clearly through reference to Brenner, Peck and Theodore's (2010) theory of "variegated neoliberalizations." Brenner, Peck, \& Theodore explain that the essence of this neoliberalization varies between policy settings so that its uptake has been uneven and variegated. "This market-disciplinary logic may take different forms in different territories, but once neoliberalism is consolidated as the world order, its constraining effect on national institutions, politics and ideologies is thought to be effectively all-pervasive" (Brenner, Peck, \& Theodore, 2010, p. 192). Neoliberal discourses such as SDD are taken up at national level variously leading to what has been termed "variegated neoliberalization" (Brenner, Peck, \& Theodore, 2010).

As this paper demonstrates, this process of relay of ideas is not seamless and involves mutations and disruptions of previous SD thought but can occur in such a way that it generates a consensus. Thus, neoliberal discourses such as SDD are a kind of prototype that move from their embryonic form within 
global institutions such as the UN, to co-evolve after mingling with policy in national contexts to mutate and take on a specific form (Brenner, Peck, \& Theodore, 2010). While retaining the focus on the logic of the market and commodification, there are nonetheless variations in its uptake to produce "hybridized institutional landscapes" (Brenner, Peck, \& Theodore, 2010, p. 189). As this case study of Environmental and EE policy demonstrates, the particular manifestation of SDD within New Zealand policy at national and local level is unique. It is the result of "co-evolutionary dynamics" and not a simple reproduction of neoliberal prototype.

The role of the TNS is in late-stage neoliberalized capitalist globalization in opening up global markets by entrenching neoliberal policy within local contexts is often neglected, especially as most analysis of neoliberalism regard it as entailing a rolling back of state intervention (Panitch, 1994). However, as Marcia McKenzie states, the "underlying assumptions embedded within global UN policy, including educational policy" deserve more academic analysis (McKenzie, 2012, p. 166). Not only do they play a role in "furthering global markets for economic activity," but UN global education policy reflects universal mandates for education that are totalizing and embedded in neoliberal logic (McKenzie, 2012, p. 166). This paper intends to address this lack of critique by examining the role and process of UN bodies (in particular the United Nations Sustainable Development Initiatives) in disseminating neoliberal global "common sense" approaches to environmentalism (greening of capitalism) and EE through an interstate "transmission belt.

By analyzing the role of the TNS in disseminating neoliberal policy globally, I am attempting more than just an academic exercise. In making visible and analyzing the processes through which neoliberal logic infiltrates policy settings our responses can be guided accordingly. The possibilities or a more genuinely deep-green/red-green response to capitalist environmental and social fallout might move from the margins.

The purpose of this paper, then, is to trace the process whereby various organizations of the UN have administered SDD, which has become hegemonic in policy and educational settings. This paper will illustrate how this process has played out in terms of broad environmental and EE policy has led to a universalizing theme in addressing environmental issues based on an underpinning shared set of "common-sense" meanings and values. In part, this SDD hegemony, which may be conceived of as an "opinion-moulding activity" has been achieved through its dissemination into national state institutions including educational policy and practice (Bieler \& Morton, 2004, p. 87).

This process has redefined the parameters of both environmentalism and EE so that they fall within the gambit of neoliberal logic. This includes the commodification of nature, a focus on managing the environment broadly 
conceived as "natural resources," environmental problem solving through technological advancement within the current economic system and the promotion of economic growth.

In response to the broad political shift from environmentalism to $\mathrm{SD}, \mathrm{EE}$ has become increasingly replaced by the term Education for Sustainability (EfS) or Education for Sustainable Development (EfSD). While some commentators in the EE field see this as a progressive evolutionary step, it is argued in this paper that this shift represents the marginalization of important radical insights about the capitalist economic order itself as the locus of the current environmental fallout. Crucially, within SDD, neoliberal capitalism becomes invisible and hence normalized.

Building on an earlier paper by Tulloch and Neilson (2014), this analysis argues that SDD is a hegemonic discourse serving to nullify previous radical environmental opposition to capitalist development. SDD, while appearing to champion the environmental cause, actually articulates it with a pro-economic capitalist growth agenda which is central to environmental degradation. The neo-liberal faith in markets and technology to produce both economic growth and ecological stability is articulated with notions of environmental protection, prosperity and individual and social well-being. This hegemonic and totalizing discourse is produced through neoliberal logic and promotes free markets and the expansion of global capitalism as the best possible solution to pre-defined issues of development (Tulloch \& Neilson, 2014).

SDD has been so readily accepted because it signifies an "original meaning" for environmentalists - many of whom subscribe to a soft-green (or technological management) approach anyway. SDD also builds on the dominant post-Enlightenment Western trajectory of progress based on economic growth and technological development that even some early environmentalists subscribed to (Tulloch, 2013).

This paper argues that SDD on the surface appears to support insights from the deep-green and red-green camps, but crucially changes their frame of reference. Now, instead of a critiquing the logic of global expansion and free-market capitalism as the basis of environmental degradation, it is taken as the very solution. The deep green position, which fundamentally rejects anthropocentric philosophy and instead attempts to regard environmental issues from a biocentric worldview, is paradoxically articulated with a pro-capitalist agenda (see e.g. Selby, 2000). The social justice agenda of redgreen thought combines an analysis of the political-economy with that of political-ecology. Previously radical environmental thought becomes compliant with the dominant Western neoliberal positioning on the environment, based as it is on human-nature separateness and instrumental market-based economic logic. 
The following section begins with a discussion of the TNS, in redesigning capitalism's institutional framework via a "model of development" (Neilson, 2012).

\section{The Transnational State and the Role of the UN in Redefining Sustainable Development and Environmental Education}

David Neilson (2012) suggests that: "The neoliberal model of development is the culminating framework within which the project of neoliberalization has been institutionalized as a global national nexus" (p. 11). Central to the neoliberal project has been a vast transformation involving ever-increasing unleashing of global capital in a manner that has resulted in reorganization of the state. The essence of this transformation has been neoliberal, with a deepening in the logic of free-markets, competition and profit. The transnational state serves the interests of the rising transnational capitalist class, whose neoliberal ideologies support the globalization of capital and are embedded in a set of political institutions (Robinson, 2001). This ideological ascendency initially crystallized in the Washington Consensus policies in the late 1980s. These polices sought to integrate national policies into regional and global economies through a set of institutions or "transnational state cadre" (Williams, 2001).

This configuration of supra-national political organizations described above makes up the transnational state (TNS). These institutions are both political (e.g. UN and the Organization of Economic Cooperation and Development (OECD) and economic (such as the World Bank (WB) and World Trade Organization WTO). Williams (2001) provides a more detailed list of TNS organizations; but the important point to note in this instance is that they form an emerging configuration that administers neoliberalized economic, social and environmental policies to national contexts (p. 167). Furthermore, they are "gradually supplanting national institutions in policy development and global management and administration of the global economy" (Williamson, 2001, p. 166). In this way national states cease to function independently and become transformed or incorporated into the TNS. Robinson (2001) argues that TNS bureaucracies are the embryonic political form of economic global restructuring.

UN organizations (e.g., UNESCO) and intergovernmental conferences (e.g., The United Nations Conference on Environment and Development (UNCED), 1992) have been central in this regard. The declarations and documents resulting from these global summits and organizations have been influential for governmental policy on environmental issues and environmental education (EE) both in New Zealand and internationally. Thus the UN is an important component of the specific capitalist state-society complex 
discussed here. The role of the UN in redefining SD is significant because it is integral to the formation of an inter-state ideological consensus, internalized in national policy and practice (Cox, 1981). The UN is the organization most responsible for making SD an internationally consensual concept, especially through the production of two documents: the Brundtland Report (World Commission on Environment and Development, 1987) and Agenda 21. The UN popularized the term "sustainable development" through the Brundtland Report, which defines it as "development that meets the needs of the present without compromising the ability of future generations to meet their own needs" (WCED, 1987). The orthodoxy of SD discourse has become so entrenched that it now informs governmental policy development nationally in New Zealand and globally and has arguably become the dominant platform for addressing environmental concerns (Dryzek, 2005).

In addition, education (both formal and informal) has been positioned by both the Brundtland Report and by Agenda 21 documents as central to achieving SD. The dissemination of SDD into the education sector has been a significant part of its overall vision. The proposal for a global framework for environmental education has been heavily influenced by UN "institutional discourses" (Berryman \& Sauve, 2013). These have come principally from the Tbilisi Declaration; The Belgrade Charter - A Global Framework for Environmental Education; and Agenda 21.

Since Agenda 21 in particular the use of "the term "environmental education" has been increasingly supplanted by terms such as "education for sustainable development" (EfSD), "education for a sustainable future" (EfSF) or "education for sustainability" (EfS) (Bolstad, 2005). This is what Lucie Sauvé calls the "sustainable development/sustainability current" and she argues that it rose to a prominence in the mid-80s and has gradually become the dominant paradigm in environmental education.

Chapter 36 of Agenda 21 states that: "Education is critical for promoting sustainable development and improving the capacity of the people to address environmental and development issues ... critical for achieving environmental and ethical awareness, values and attitudes, skills and behavior consistent with sustainable development" (United Nations Conference on Environment and Development, 1992, p. 2). Thus the formal establishment of the concept of Education for Sustainable Development (ESD) at the 1992 Rio de Janeiro United Nations Conference on Environment and Development (UNCED), has given governments internationally, and in New Zealand, a base from which to launch their own curriculum initiatives (UNCED, 1992).

Dissemination of a pro-business, large scale corporate neoliberalized version of SD has not always proceeded smoothly however. Richard Kahn (2008) detailed how at the 2002 Earth Summit held in Johannesburg South Africa (The World Summit for Sustainable Development (WSSD)) definite 
divisions and resistance to the dominant SDD emerged. Central to the tension was the refusal of the WSSD (or W\$ $\$ D$ as it was dubbed by critics) to ratify "the holistic, pointedly socialist in spirit, and non-anthropocentric Earth Charter educational framework" (Kahn, 2008, p. 7). The ideological struggle was principally between "large-scale corporate and governmental technocrats and the more grass-roots based theorists, activists and educators proper" (Kahn, 2008, p. 7). Instead of the ratification of the Earth Charter, EfS was promoted as the favored form of inter-disciplinary education to be integrated into all levels of schooling (Kahn, 2008). This was followed by the United Nations declaration of a Decade of Education for Sustainable Development (DESD) during 2005-2014.

This section has discussed the UN as a transnational interstate apparatus that has been central in producing and integrating dominant neoliberalized SDD into global agreements. In the next part of this paper the way in which this became disseminated through the interstate transmission belt to the New Zealand environmental and EE policy context will be discussed.

\section{The New Zealand Context}

As discussed above, the dominant UN discourse on SD has been articulated with ideologies circulating in local policy settings in New Zealand. This section will outline some of the key developments in New Zealand's government policy on SD that have been a result of this process. The way this has occurred is not simply a top-down one-way reproduction of SDD in national and local contexts. Neoliberalization of environmental policy settings in New Zealand is a result of a reworking of New Zealand's specific institutional landscape (Brenner, Peck, \& Theodore, 2010). The articulation of SDD with discourses already in situ - that is a unique and specific national policy setting - is at the heart of variegated neoliberalization (Brenner, Peck, \& Theodore, 2010). New Zealand's unique environmental, socio-political and economic context influences the ways in which the transmission process has taken (and continues to take) place. Thus before going into any detail regarding the transmission of SDD into New Zealand policy settings it is important to provide a brief contextual background.

Significant environmental degradation is a concern for New Zealand. Despite the power of the place-based myth of New Zealand as "clean and green," the reality is somewhat different (Bell, 1997; Ateljevic \& Doorne, 2002). The process of "settling New Zealand" by early European colonists, including the forced alienation of Maori from their land, and has resulted over time in ecological degradation of its exceptional endemism and a loss of biodiversity. Over-exploitation of natural resources, over-harvesting of marine life and habitat destruction caused by the introduction of alien species 
and the conversion of primary vegetation to farm land has precipitated ecological degradation. New Zealand's remarkable array of ecosystems, including distinctive evergreen forests, wetlands, grasslands and marine environments are now under threat (Eames \& Barker, 2011).

Much environmental degradation recorded in the last thirty years has coincided with the neoliberalization of economic and social policy. Since 1984 and the Labour Government return to power after nine years in opposition, New Zealand moved from a Keynesian welfare state to a neoliberal postwelfare state. This led to the restructuring of the welfare state, economy and public sector in line with neoliberal ideology. With its focus on privatization, deregulation, freeing trade barriers and economic growth, it is unsurprising that there have been associated increases in social inequality and environmental degradation (Boston, 2014).

The neoliberalization of New Zealand economic and social policy has been theorized in academic literature (see e.g. Boston, 2014; Cooke, Hill, Baskett, \& Irwin, 2015; Hackell, 2013; Jesson, 1999; Olssen \& Peters, 2005; Peters, 2011), and it is generally accepted that the neoliberal ideology informs its national policy settings. Neoliberalism in New Zealand is inextricably connected with globally defined imperatives of capitalist development and unleashing of global capital. SDD serves well as an ideological Trojan horse in this regard, concealing the overriding neoliberal economic growth agenda through articulating it with liberal-left aspirations of social equality and environmental protection.

\section{The Dissemination of Neoliberalized Sustainable Development Policy in New Zealand}

New Zealand let the SDD Trojan horse willingly through its gates. However, the process through which it appeared in divergent policy settings is an interesting study in way that the transnational transmission belt works. Brenner et al. (2010) refer to this as "transversal manoeuvres across divergent institutional sites." So we find SDD appearing in UN (at a global level) and at the same time in the policy of various New Zealand government bodies, and NGOs and government watchdog sites. It is not a simple downward unidirectional transferral. The focus of this section is on SDD's institutionalization in mainstream New Zealand government policy. This section demonstrates the reworking of the New Zealand environmental institutional landscape as a result of UN neoliberalization processes. This has involved cross-over and co-evolution of SDD across a global and national context.

Though not without its struggles, in the last three decades a dominant discursive formation has emerged that favors the "weak" version of sustainability ("business as usual" in a greener and more eco-friendly) way has taken 
shape in New Zealand. Principally this has taken the form of government bodies adopting UN discourse on SD to establish links between social and environmental concerns and the economy. Bebbington, Higgins, \& Frame (2009) found that:

\begin{abstract}
The emphasis is on fairly traditional responses to a fluctuating external environment (efficiency, technological innovation, technoscientific management, procedural integration and coordinated management). Couched within economic utilitarianism, current articulations ... present little critical challenge and thus continue to normalize many unsustainable practices (Bebbington, Higgins, \& Frame, 2009, p. 7).
\end{abstract}

Furthermore, they say that dialogue about the priorities in NZ's economic, environmental, social and cultural sphere are controlled by "relatively small group of elites" rather than the public (Bebbington, Higgins, \& Frame, 2009, p. 6).

Agenda 21 has been particularly influential in environmental policies and legislation in NZ since the 1990s (UNCED, 1992). Agenda 21 clearly stated that environmental concerns needed to be integrated with development. Indeed it went further to signify a particular kind of economic development:

(c) To include, wherever appropriate, the use of market principles in the framing of economic instruments and policies to pursue sustainable development (The United Nations Conference on Environment and Development (UNCED), 1992).

Prompted by Agenda 21, changes to New Zealand's environmental policies and legislation in the 1990s and beyond have come primarily from the New Zealand Government, particular the Ministry for the Environment (MfE). Other central participants have included the Parliamentary Commissioner for the Environment (PCE) an independent environmental watchdog. The NZ Business Round Table has also "attempted to assert the normative legacy of economy-centered understandings" of sustainability (Bebbington, Higgins, \& Frame, 2009, p. 7).

Below is a timeline of some of the key developments in the uptake of SDD in New Zealand policy frameworks. It demonstrates the way in which SDD, through the interstate transmission belt function, became a core part of environmental and EE policy narrative in New Zealand. It also indicates the profound economic utilitarianism that has been the basis of SDD in New Zealand policy settings.

Even before Agenda 21 the New Zealand government's was sitting up and taking notice of SDD. The New Zealand government's initial commitment to the SDD was established in ground-breaking legislation in the early 1990s 
(The Resource Management Act, 1991). SD became a central feature of the Resource Management Act (RMA) in 1991:

In this Act, sustainable management means managing the use, development, and protection of natural and physical resources in a way, or at a rate, which enables people and communities to provide for their social, economic, and cultural well-being and for their health and safety (New Zealand Government, 1991).

This was followed in September 1995 by the release of released Environment 2010 Strategy (E2010) by the Ministry for the Environment (MfE). The E2010 is a statement of environmental priorities and strategies, the first to be developed by a New Zealand government. It was designed to "complement the Government's economic growth strategy, released in June 1993 as Path to 2010" (McGuiness Institute, n.d.) The coupling of environmental and economic growth concerns is clearly indicated.

In 1997, the New Zealand government was among other UN member states in agreeing at a Special Session of the UN General Assembly (UN, 1997) to introduce a National Sustainable Development Strategy (NSDS) by 2002. However, by 2003 no such NSDS had been prepared however; and in 2003 the MfE instead released the Sustainable Development Plan of Action. Successive Labour governments introduced legislative and normative initiatives including a SD strategy for New Zealand and the Local Government Act (2002) which embedded SD in local government legislation (Bebbington et al., 2009). Contributors to the SD strategy included Ministry of Economic Development, Treasury, Ministry of Foreign Affairs and Trade, Ministry for the Environment and Ministry of Social Development.

In 2000 Cabinet had formally adopted the Brundtland Report SD definition, acknowledging that this involves the integration of social, environmental and economic dimensions (McGuiness Institute, n.d.).

Increases in measuring sustainable outcomes are another indicator of the increasing institutionalization of SDD in government policy. In August 2002 a report was released by Statistics New Zealand entitled "Monitoring Progress Towards a Sustainable New Zealand" (Statistics New Zealand, 2002). Themes in this report included both "environment and ecosystem resilience" and "economic growth and innovation" (p. 12). A focus on balance was evident in the question "Is the economy innovative and growing ... and in balance with the environment"? (p. 10). The assumption of economic growth as an unqualified good was coupled with "innovation." This is a hallmark of neoliberalized sustainable development: the assumption being that environmental issues can be resolved both by and through technological innovation, new markets and economic growth. 
Thus, consecutive governments in New Zealand have, since the early 1990 s, signaled a clear commitment to SD. They have also expressed a desire to achieving equilibrium between the three pillars, although the premising of the economic pillar is evident. Prime Minister Helen Clark even enthusiastically endorsed another pillar, that of "nationhood" in her 2007 opening speech:

I believe New Zealand can aim to be the first nation to be truly sustainable across the four pillars of the economy, society, the environment, and nationhood. I believe we can aspire to be carbon neutral in our economy and way of life ...I do believe New Zealanders value our country's clean and green, fair and inclusive status, and our first world living standards (Helen Clark, 2007).

In signifying a particularly unique national response to the SD imperative (framed in the neoliberal language of commodification), Clark was evoking nationhood and national identity (way of life). Her speech may have rallied her supporters and been accepted by centre left, but it was amiss in addressing how New Zealand's "nationhood" is now inextricably tied to the global capitalist imperative and what constraints this might put on such a vision. Conversely, links to the global economy were seen by Helen Clark as central to any move toward a sustainable nation (Clark, 2007). Any reference to the intrinsic value of a healthy environment was notably absent from this speech. Instead, the extrinsic value of a carbon-neutral economy to New Zealand was pushed home. New Zealand's relative isolation from the rest of the world has often been a vulnerable point and Clark had no hesitation in exploiting it. She stated that:

New Zealand's future is dependent on long term sustainable strategies for our economy, society, environment, culture and way of life...In our high value markets in Europe, we face increasing pressure on our trade and tourism, from competitors who are all too ready to use against us the distance our goods must travel to market, and the distance tourists must travel to us. By lowering our carbon footprint, we strengthen our position against that kind of protectionism - and the government is working to lower that footprint in many ways (Helen Clark, 2007).

In the above speech, the neoliberal language of "markets" and "competition between nations" was articulated with a sense of "nationhood;" ensuring New Zealanders "buy-in" to the discourse. This has been central to New Zealand political discourse and the promulgation of certain cultural values such as fairness, equality, social mobility, love of the great outdoors, conservation and 
access to public goods (including beaches, national parks) (Coyle \& Fairweather, 2005).

In 2008 Statistics New Zealand published "Framework for Measuring Sustainable Development" (Statistics New Zealand, 2008); and in 2011 "Key Findings on New Zealand's Progress Using a Sustainable Development Approach: 2010" (Statistics New Zealand, 2010). The dominant language of SDD was used in this report:

Meeting needs of current and future generations, while taking into account considerations of fairness and limits of the environment, is a complex challenge. To represent this complexity three interrelated target dimensions are used. These are: environmental responsibility, economic efficiency, and social cohesion (Statistics New Zealand, 2010, p. 21).

This increased monitoring of SD indicators, revealed some important trends such as an increase in income inequality and unemployment. It also indicated an increase in total greenhouse gas emissions. Other environmental indicators included an increase in nitrogen in rivers, and decline in distribution of selected native species. On the other hand there was a positive trend in labor productivity and assets and infrastructure. Clearly the desirable "balancing act" referred to by Statistics New Zealand was not being achieved. The economy continued to grow regardless of the social and environmental fallout. Despite referring to the importance of "ecological limits," it would appear Statistics New Zealand was unable to present a report indicating that New Zealand was living within them.

This privileging of the economy has been enduring in governmental policy on sustainability in New Zealand. It was a strong focus of the BlueGreen Report released by the National Government in May 2006 which among other principles indicated that: "economic growth and improving the environment can and must go hand in hand." This principle was repeated in the 2012 version of this report along with signaling the centrality of the environment to "our international reputation, our primary sector, our growing tourism market, and our economy" (The New Zealand National Party, 2012). In addition it is noted in the principles that science is of high import to social decision making around environmental issues and that incentives are important when asking people to respond to change. The commitment to Enlightenment values of progress, growth, individualism and the neoliberal emphasis on the selfinterested individual are evident (The New Zealand National Party, 2012).

In 2015 the UN General Assembly formally accepted 17 Sustainable Development Goals, which have in turn been endorsed by the current National Government. "New Zealand welcomes the ambition contained in the Sustainable Development Goals. And we support the substance of the Goals" 
(National Party, n.d.). Among the goals of ending poverty and hunger and promoting equitable quality education and gender equality was the ubiquitous goal of economic growth. This includes the targets of: "Sustain per capita economic growth" and "[a]chieve higher levels of economic productivity through diversification, technological upgrading and innovation." Of interest was the goal of "endeavor to decouple economic growth from environmental degradation." While other goals are more forthright, the meekness of "endeavor" indicates that perhaps, it is not essential that we do so, only desirable. The very possibility of being able to decouple environmental degradation from economic growth under globalised capitalist production is, of course, not addressed.

The above section has demonstrated that SDD in New Zealand environmental policy, broadly speaking, has a definite neoliberal substance. This is primarily framed in terms of the articulation of economic growth and free markets with technology, innovation, entrepreneurial diversification and resource management. This decidedly anthropocentric orientation to the environment has become institutionalized within New Zealand policy settings.

The question remains as to the uptake of SDD in education policy. Developments here have reflected the broader policy contexts, with EE policy statements lifting quotes directly from both UN sources and the MfE. In 2004 the Parliamentary Commissioner for the Environment (PCE) claimed that environmental education (EE) in New Zealand was demonstrating, "growing pains of a movement stretching to embody a huge vision - a vision that environmental education has always shown some characteristics of, but which it now needs to manifest more proactively" (PCE, 2004, p. 39). This explicit endorsement of education for sustainability (EfS) was published just a year before the United Nations Decade of Education for Sustainable Development was proclaimed by the UN General Assembly following the Johannesburg Summit. This was to be a ten-year period beginning 1 January 2005.

We are now at the end of this decade, and the transition from EE to EfS in New Zealand predicted by the PCE has not fully materialized, but is rather piecemeal and elusive. The word "sustainability" is liberally referred to in the most recent curriculum document, particularly at the front end which outlines the normative underpinnings of the curriculum (MoE, 2007). Yet neither EE nor EfS are a separate learning area within this document and many commentators have taken issue with the perceived lack of support from the government (see e.g. Chapman, 2011). Despite this, the language of "sustainability" and "sustainable development" has become integrated into curriculum mandates.

The language of sustainability became institutionalized in New Zealand education policy primarily from the 1990s onward. In response to UN global initiatives which called for environmental education in formal and non- 
formal educational sectors, the New Zealand Natural Heritage Foundation organized and international environmental conference in 1991 entitled Our Common Future: The Way Forward. This is of course a rehearsal of the World Commission on Environment and Development report entitled "Our Common Future," which elaborated a global long-term strategy for sustainable development up to the year 2000 and beyond (Schubert \& Lang, 2005).

This upsurge in global and national push for environmental education also came from the Ministry for the Environment (MfE) who launched Learning to Care for Our Environment: A National Strategy for Environmental Education in 1998 (Ministry for the Environment, 1998). This was followed by the publication of Guidelines for Environmental Education in New Zealand Schools (New Zealand Ministry of Education, 1999).

A national research project on Environmental Education policy and practice in New Zealand schools undertaken by The New Zealand Council for Educational Research and the University of Waikato between 2002-2003 investigated the characteristics of EE policy and practice in New Zealand (Bolstad, Cowie, \& Eames, 2004) This report suggested that EE policy in New Zealand had undergone a re-orientation toward EfS in response to international drivers such as the UN, and in particular the 1992 Rio Summit. "International summits and declarations, as well as New Zealand's own environmental management policies and obligations to the Treaty of Waitangi, have influenced environmental education policy developments in New Zealand" (Bolstad, Cowie, \& Eames, p. 25). This report suggested that in New Zealand, cross governmental connections have been important in strategic leadership to orient New Zealand EE toward EfS: in particular the Ministry for the Environment, the Ministry of Education and the Department of Conservation. Connections across different national policy sectors illustrate the "pathways of neoliberalization" discussed by Brenner, Peck, \& Theodore (2010).

According to Bolstad, Cowie, \& Eames (2004), despite policy orientation toward EfS, in practice EE had largely remained as the discourse within schools. They also suggested that EE had been pushed to the margins in formal schooling because of its non-mandatory status. This report highlighted the significance of enthusiastic teachers, NGOs and the highly successful non-government funded program Enviroschools in developing whole-school, action-based, issues oriented EE pedagogy.

An update of this report was published in 2015 by the NZCER (Bolstad, Cowie, \& Hipkins, 2015). This report referred to the range of interest groups involved in EE/EfS policy as "stakeholders," and called for "a more coordinated central policy framework, aligning across MoE, MfE, and DoC priorities to support and give direction to EE/EfS" (Bolstad, Cowie, \& Hipkins, 2015, p. 13). This largely acritical approach takes for granted the 
reorientation of EE toward EfS in New Zealand policy settings, being largely supportive. It indicates the level of institutionalization and acceptance of SDD in EE policy settings in New Zealand.

\section{Case Study: New Zealand Environmental Education Policy}

This paper now turns to an analysis of environmental education policy in New Zealand, focusing on two dominant policy documents: Guidelines for Environmental Education in New Zealand Schools (Ministry of Education, 1999) and The New Zealand Curriculum (Ministry of Education, 2007). I will be focusing particularly on the "dense entanglements, interdependencies and interconnections" between the UN as a transnational interstate apparatus disseminating neoliberal logic, and the New Zealand national policy context (Brenner, Peck, \& Theodore, 2010, p. 217). This illustrates how the neoliberalization process is variegated in character, resulting in institutional divergence across geographical settings, yet still retains a unitary global neoliberal blueprint for development (Brenner, Peck, \& Theodore, 2010).

The reason for examining the Guidelines is that, despite being published fifteen years ago, it represents the most recent policy statement aiming to give direction to schools and teachers in integrating $\mathrm{EE}$ into their existing curriculum programs (Eames, Cowie, \& Bolstad, 2008). While not making EE compulsory, the Guidelines provided examples of how it could be integrated across the seven learning areas covered in the then curriculum The New Zealand Curriculum Framework (Ministry of Education, 1993). When this curriculum was updated and replaced in 2007 with The New Zealand Curriculum (Ministry of Education, 2007), there was no corresponding development of the Guidelines which remained unchanged. Despite this, the Guidelines importance as a critical (albeit out of date) document for schools wishing to implement EE is significant.

\section{Guidelines for Environmental Education in New Zealand Schools}

The Guidelines for Environmental Education in New Zealand Schools was released in 1999 and provided direction for schools interested in integrating EE into the various learning areas in the school curriculum. It mirrors and endorses many of the policies coming from the UN, often making direct reference to them. For example there is almost verbatim recalling of the EE objectives as identified in the Tbilisi Declaration. These included a focus on the development of knowledge, skills, behavior, attitudes and values. It was paraphrased in the 1999 Ministry of Education (MOE) publication, Guidelines for Environmental Education in New Zealand Schools: 
Environmental education is: a multidisciplinary approach that develops the knowledge, awareness, attitudes, values and skills that that will enable individuals and the community to contribute towards maintaining and improving the quality of the environment (MoE, 1999, p. 9).

The Guidelines demonstrates a clear link to Agenda 21 and advocated for a "sustainable future" in the very first sentence of the foreword written by Howard Fancy (then Secretary for Education). In fact the focus on a "sustainable future" is connected explicitly to the Government's Environmental 2010 Strategy. This is quoted extensively in the introduction to the Guidelines where the overarching goal of sustainability was broken down into a vision including that of "sustainable development that meets the needs of present and future generations" (MoE, 1999). The Guidelines then go on to say, "[e]ducation for sustainability is a new focus for education. It is a way of helping individuals and societies to resolve fundamental social issues related to the current and future use of the world's resources" (MoE, 1999, p. 8).

The Guidelines informs us that people have "modified the land, introduced plants and animals, and utilized both renewable and finite resources" (p. 6) and argues that the maintenance and improvement of environmental quality is important. Environmental issues and problems are depicted within the Guidelines as the responsibility of individuals and groups. There is also reference to natural and physical resource limits and resource management. This is illustrative of a soft-green technicist/ management discourse on the environment that links so well to SDD and the dominant discursive formation in New Zealand policy settings referred to earlier by Bebbington, Higgins, \& Frame (2009).

The Guidelines also identifies four key concepts underpinning EE including "interdependence," "biodiversity," "sustainability" and "personal and social responsibility." While acknowledging that sustainability is subject to multiple interpretations, the Guidelines argues that it is linked to the "concept of sustainable resource management" (MoE, 1999, p. 12). It also argues that it is "at the heart of the Resource Management Act, 1991. This Act ... defines its purpose as promoting the sustainable management of natural and physical resources" (MoE, 1999, p. 12). Sustainability is depicted in terms of sustaining resources for future generations in order to meet their "reasonable demands" (although these are not clarified) (MoE, 1999, p. 12).

Here there is a definite level of discursive congruence between policy at the global level (between the UN and New Zealand policy) and the subnational level (between environmental policy and educational policy sectors). Furthermore, the strong cultural mores evident in New Zealand for conserving 
the unique biodiversity and managing our resources link well with SDD's focus on future generations and environmental sustainability.

However, the critical shift from previous EE in NZ comes with a new focus on the economy. This is slipped into the discourse of EE through the concept "interdependence." Interdependence is a concept all ecologists and environmentalists will be familiar with. In ecological terms it focuses on the critical relationships between living things and the natural elements within ecosystems. This kind of "systems thinking" now becomes extended in the Guidelines and SDD to refer to how the environment, the social system and the economy are interrelated.

[T]he environment is ... a set of interrelated systems - the biophysical, social, economic, and political systems.... The biophysical system provides life-support systems for all life. A social system provides rules and structures that enable people to live together. An economic system provides ways of producing and exchanging goods (MoE, 1999, p. 11).

This largely apolitical version of the interdependence of biophysical, social and economic systems gives some indication of the anthropocentric view of nature that goes hand in hand with the naturalization of the economy. Nature is rendered invisible, except as a biophysical entity "out there" providing life support. The environment is natural, social and economic systems collapsed into one, and in this way the social and economic become "naturalized" and common sense. Nature, as environment, becomes something separate from us. The economy becomes "natural;" simply the way that humans produce and exchange goods.

The Guidelines also advocates values education in which students are to develop a sense of "shared values integral to New Zealand society." This constitutes a form of citizenship education closely linked to Governmental objectives: "environmental education provides an effective means of achieving the Government's goals for both education and the environment" (MoE, 1999, p. 6). This includes the Environment 2010 Strategy that the purpose of EE is to "encourage environmentally responsible behavior and informed participation in decision-making by promoting environmental education throughout the community" (p. 6). In addition lifestyle choices/actions of individuals depicted as central to environmental quality and people are regarded as central in solving environmental problems (p. 13). That individual and social decision making is seen as the primary impact on environmental quality and takes precedence over political and economic factors ignores the larger structural reality that late-stage capitalist production is at the root of current environmental degradation. 


\section{The New Zealand Curriculum (NZC)}

There is repeated reference to sustainability and sustainable development in the front end of the NZC. The Ministry of Education website Te Kete Ipurangi (TKI) supports this holistic positioning: "The future-focus theme of sustainability is evident throughout The New Zealand Curriculum. It is integral to the vision, principles, values, and key competencies, and provides relevant and authentic contexts across the eight learning areas" (MoE, 2015).

The NZC claims that it enables students "to successfully create, contribute to, and participate in a sustainable future" (MoE, 2007, p. 7). The vision is for students who are: "connected to the land and the environment," "members of communities" and "international citizens" (MoE, 2007, p. 8). They will "seize the opportunities offered by new knowledge and technologies to secure a sustainable social, cultural, economic, and environmental future for our country" (MoE, 2007, p. 8). The curriculum is here inciting particular citizen political subjectivities. This focus on New Zealand citizenship provides interesting insights: here is a citizen who is connected to environment and is able to engage effectively within communities, and yet also participate on an international level. In addition s/he will be able to use relevant knowledge and technologies to construct a sustainable social, environmental and economic future. The economic future is assumed, taken for granted and never questioned.

The "key competencies" provide considerable insights into the subject premised in the NZC, especially those of "managing self" and "participating and contributing." "Students who manage themselves are enterprising, resourceful, reliable and resilient" (MoE, 2007, p. 12). The individualism premised here is coupled with the neoliberal focus on "responsibility" and "communities" and tied in with future sustainability. "Students who participate and contribute in communities ... understand the importance of balancing rights, roles and responsibilities and of contributing to the quality and sustainability of social, cultural, physical and economic environments" (MoE, 2007, p. 13). The particular citizen-subject version constructed here can be aligned with neoliberal rationality: the coupling of a morally responsible individual and an economic-rational actor. Through the regulationist characterization of neoliberalism, education becomes a mechanism that "redraws subjectivities" to create new "modes of citizenship" (Raco, 2005).

Further development of EfS is evident on TKI. The focus on individual responsibility is continued here where environmental stewardship is reduced to: "the choices and actions we can take to prevent, reduce, or change harmful activities to the environment" (MoE, 2015). Included is a model of EfS by Barry Law that promotes: "Attitudes and values that lead to create a nation of innovative and motivated people who think and act sustainably" (MoE, 
2015). This focus on "willingness to act" and the "correct" attitudes and values is at odds with a critical and transformative approach to EfS.

This section has demonstrated that recent EE policy development in New Zealand has been "path-dependent;" that is, it has been substantially dependent on the UN in its formation. In addition it is also the result of pathways formed between policy settings in New Zealand and the UN. It is a complex process with common underlying neoliberal parameters (Brenner, Peck, \& Theodore, 2010, p. 219).

\section{The Neoliberal Substance of SDD-led EE Discourse in New Zealand}

Despite its unique New Zealand flavor, SDD led EE policy in New Zealand is set within the parameters of neoliberal logic. The dominant forms of knowledge privileged in the Guidelines may be regarded as anthropocentric and instrumentalist (soft-green managerialist) rather than deep-green or red-green. Through the soft-green lens, the non-human world is regarded as separate from the human world; one that can be "managed." This can lead to the casting of non-human nature as a "class of other beings that are available to be treated without ethical constraints as resources or commodities" (Plumwood, 2002, p. 12). The capitalist logic of exploitation extends to an "Otherwisation of nature" that has become common sense within curriculum policy statements and taken for granted. While spaces for resistance may be revealed within scientific ecology and its focus on interconnectivity, these are dampened by "long standing insensitivities and rationalist distortions in a wide range of areas, including knowledge itself" (Plumwood, 2002, p. 10). Thus, contesting the dominance of particular forms of cultural knowledge and their expression in school curriculum policy is not just a matter of "adding on" more ecologically sensitive understandings. When knowledge itself is considered mostly in mechanistic and instrumental terms (the hidden curriculum) then more radical ecological insights may well become subsumed.

The Guidelines demonstrated a similar approach to learning as that in the Belgrade Charter and Tbilisi Declaration. The focus is on the subject "environmental education" as the vehicle through which the student develops a presumably pre-determined knowledge set, along with the skills, awareness and appropriate values to maintain and improve the environment. As a form of citizenship education, EE aims to develop individual responsibility, behavior and attitudinal change, particular values and pro-environmental action (Gough, 2013). Broadly speaking EfS/ESD has been regarded as a vehicle for the development in students of particular pro-environmental values and attitudes. In addition, a stated goal of environmental education is the preparation of future citizens prepared to take environmental action. 
The assumption that knowledge is to be developed in students primarily in order to maintain and improve the environment is based on a view of knowledge that is instrumental in nature. Lotz-Sisitka et al. (2013) draw on Habermas to argue that education based on instrumental knowledge reflect a desire by humans to master and control the physical world. It is based on positivist scientific models and behaviorist approaches to environmental education. The focus on student performance and the development of proenvironmental behavior are key features of an instrumental-technicist educational approach.

Giroux (2001) argues that this type of approach is based on a technical rationality. The presumptions about knowledge are that it starts from the concrete, or "hard data" through which abstractions and generalizations are made (Giroux, 2001). The privileging of this kind of knowledge can be seen in the Guidelines with the description of education in the environment. This pedagogical technique involves taking students "beyond the classroom in both natural and built environments" (MoE, 1999, p. 14). The purpose of this endeavor is to provide opportunities to "develop skills in observation, data collection, practical inquiry and investigation, and the use of specialist technology" (MoE, 1999, p. 14). A concrete grounding such as this is said to help students "develop an appreciation of and a concern for the environment" (MoE, 1999, p. 14).

The conditions through which students may reflect have already been framed in scientific and technological terms, enframing what is knowable and valuing nature in terms of its "potential to serve human needs" (Bonnet, 2003). As Bonnett (2003) argues, "our underlying stance on nature's value will determine how environmental problems will be conceived and the kinds of answers that will be sought, that is, what will count as an answer. It will thus determine the kinds of knowledge and understanding to be considered relevant, and, fundamentally, what the ethical basis for judging policy and action will be" (Bonnett, 2003, p. 556).

Predominant EE/EfS approaches in schools have focused on individual behavior and attitudinal change and favor a natural science perspective on environmental issues (Kyburz-Graber, 2013). The vision is for responsible citizens equipped with a package of skills, understandings, knowledge, attitudes, values and competencies to actively engage with environmental issues. While championing a critical pedagogical approach, this is actually a form of domestication.

The anthropocentric bias is often not analyzed in discussion of environmental education (Kopnina, 2012). Yet our very alienation from nature and dislocation on earth should make this one of the most pivotal concerns. As humans our existential drama is the very stuff of a truly transformative and critical EE pedagogy. There are important areas of recent critique from re- 
searchers favoring socioecological and/or postmodernist frameworks (Gough, 2013).

The anthropocentric bias of neoliberal logic has been challenged by scholars in the field (see e.g. Castree, 1995; Kahn, 2008). Neoliberalism supports the dominant Western neoliberal positioning on the environment, based as it is on human-nature separateness and instrumental market-based economic logic. As McKenzie states: "Neoliberalism builds on a western trajectory of cultural norms and practices, including hierarchical dualisms of individual over social, human over environment, and industrialized or 'developed' over non-industrialized" (McKenzie, 2012, p. 165).

Dominant institutionalized responses to our current environmental and related social crises are clearly framed within the same logic that produced them. Yet it is not enough to challenge the ideologies that support the current globalized neoliberal regime and attempt to replace them with ecocentric and socially democratic progressive ideologies at a national level. Any counterhegemonic response to neoliberalization of EE policy needs to carefully consider the global-national relation described above (Neilson, 2015). The response needs to include consideration of a global alternative model of development (Neilson, 2015) and not simply a transformation of values from soft-green to a more deep-green hue. As Neilson (2015) suggests, we need to "create a trans-national environment more compatible with progressive social reform at the national level" (p. 202). Deep-green and red-green premises may well be the basis of a counter-movement, but they need to inform a global model of development and not simply a national one.

From an educational point of view at least, ecopedagogy is an approach worthy of consideration. It counters anthropocentric bias of SDD and engages students in developing awareness of the ecological bottom line. It addresses not only planetary concerns, but also those that are place-based (Kahn, 2008).

\section{Conclusion}

The neoliberalized global world capitalist order is characterized by the ability of an economic elite to establish power through ideological means. This paper has demonstrated that New Zealand policy settings have become directly subordinated to the process of neoliberalization by the TNS; in particular the $\mathrm{UN}$ as an ideological interstate apparatus. Education is implicated in the process through which hegemony is created in an attempt to neutralize resistance to neoliberal capitalist expansion as described above. Principally the UN has been significant in disseminating universal and totalizing mandates for EE in the form of EfS/EfSD. This has occurred through supranational circuits that operate to disseminate neoliberal logic in a variegated fashion as it comes into contact with particular national settings. 
This paper has demonstrated that environmental policy broadly speaking and more specifically environmental education policy in New Zealand has filtered from high UN global summits, increasingly dominated by neoliberalized SDD. While neoliberalism takes variegated forms, the UN has nonetheless been successful in promoting a homogenization of environmental thought based in the last instance on neoliberal logic.

Education can be a critical part of a counter-movement. Currently EE policy and school curricula in general function to domesticate students into the status quo. As Giroux (2001) argues, our consciousness is constituted in our perceived needs, our unconscious activity and in our common sense assumptions about everyday life. SDD embraces the contradictions of capitalism and ecological integrity, building on Enlightenment ideas regarding the benefits of technological progress and economic growth. Our "needs" as humans, framed within the logic of capitalism, are further supported by SDD. SDD encourages conscious consumerism and a responsible citizenry, who resolve environmental issues through technology and innovation, are selfgoverning with the "right" pro-environmental attitude and behaviors. This is the neoliberal substance of SDD, reflected in EfS/EfSD curriculum policy.

It follows that EfS/EfSD, in disseminating the attitudes, norms and values of sustainability culture through curriculum, is an act of domestication (Freire, 1970/2005). As demonstrated in this article, EfS/EfSD does not engage students in a critical exploration of the unsustainability of the material conditions of production framing their everyday lives. Instead, it supports the massification of humans within the context of a highly technological, stratified and complex global social order. The universalizing tendencies of SDD, produced in part by UN institutions, and disseminated through EfS/EfSD curriculum policies, functions to domesticate, not liberate.

An ecopedagogical approach, such as that suggested by Richard Kahn can empower students to develop the critical thinking capacities to challenge the environmentally, socially and species exploitative norms of neoliberal logic.

\section{REFERENCES}

Ateljevic, I. (2001), "Searching for Nature and Imagining New Zealand," Journal of Travel and Tourism Marketing 10(1): 115-122.

Ateljevic, I., \& Doorne, S. (2002), "Representing New Zealand Tourism Imagery and Ideology," Annals of Tourism Research 29(2): 648-667.

Bebbington, J., Higgins, C., \& Frame, B. (2009), "Initiating Sustainable Development Reporting: Evidence from New Zealand," Accounting, Auditing and Accountability Journal 22(4): 588-625.

Bell, C. (1997), "The 'Real' New Zealand: Rural Mythologies Perpetuated and Commodified," The Social Science Journal 34(2): 146-158. 
Berryman, T., \& Sauve, L. (2013), "Languages and Discourses of Education, Environment and Sustainable Development," in R. Stevenson, M. Brody, J. Dillan, \& A. Wals (eds.), International Handbook of Research on Environmental Education. New York and London: Routledge, 133-155.

Bieler, A., \& Morton, A. (2004), "A Critical Theory Route to Hegemony, World Order and Historical Change: Neo-Gramscian Perspectives in International Relations," Capital\&Class 28(1): 85-113.

Bolstad, R. (2005), "Environmental Education: A Place in the Curriculum?," New Zealand Annual Review of Education 14: 215-235.

Bolstad, R., Cowie, B., \& Eames, C. (2004), Environmental Education in New Zealand Schools: Research into Current Practice and Future Possibilities. Vol. 1: Summary of the Research Findings. New Zealand Council for Educational Research.

Bolstad, R., Joyce, C., \& Hipkins, R. (2015), Environmental Education in New Zealand Schools. New Zealand Council for Educational Research.

Bonnett, M. (2003), "Chapter 1. Introduction: A Tangled Web," Journal of Philosophy of Education 37(4): 551-562.

Boston, J. (2014), "Child Poverty in New Zealand: Why It Matters and How It Can Be Reduced," Educational Philosophy and Theory 46(9): 962-988.

Brenner, N., Peck, J., \& Theodore, N. (2010), "Variegated Neoliberalization: Geographies, Modalities, Pathways," Global Networks 10(2): 182-222.

Carruthers, D. (2005), "From Opposition to Orthodoxy: The Remaking of Sustainable Development," in J. Dryzek, \& D. Schlosberg (eds.), Debating the Earth: The Environmental Politics Reader. New York: Oxford University Press, 285-300.

Castree, N. (1995), "The Nature of Produced Nature: Materiality and Knowledge Construction in Marxism," Antipode 27(1): 12-48.

Clark, H. (2007), The Official Website of the New Zealand Government. Retrieved from Beehive.govt.NZ: https://www.beehive.govt.nz/speech/prime-minister\%E2 $\% 80 \% 99$ s-statement-parliament

Chapman, D. (2011), "Environmental Education and the Politics of Curriculum: A National Case Study," The Journal of Environmental Education 42(3): 193-202.

Cooke, D., Hill, C., Baskett, P., \& Irwin, R. (2015), Beyond the Free Market: Rebuilding a Just Society in New Zealand. Auckland: Dunmore Publishing.

Cox, R. W. (1981), "Social Forces, States, and World Orders: Beyond International Relations Theory," Millenium Journal of International Studies 10(2): 126-155.

Coyle, F., \& Fairweather, J. (2005), "Challenging a Place Myth: New Zealand's Clean Green Image Meets the Biotechnology Revolution," Area 37(2): 148-158.

Doyle, T. (1998), "Sustainable Development and Agenda 21: The Secular Bible of Global Free Markets and Pluralist Democracy," Third World Quarterly 19(4): 771-786.

Dryzek, J. (2005), The Politics of the Earth. Oxford: Oxford University Press.

Eames, C., \& Barker, M. (2011), "Understanding Student Learning in Environmental Education in Aotearoa New Zealand," Australian Journal of Environmental Education 27(1): 186-191. 
Eames, C., Cowie, B., \& Bolstad, R. (2008), "An Evaluation of Characteristics of Environmental Education Practice in New Zealand Schools," Environmental Education Research 14(1): 35-51.

Freire, P. (1970/2005), Pedagogy of the Oppressed. New York: Continuum.

Giroux, H. (2001), Theory and Resistance in Education. Westport: Bergin and Garvey.

Gough, A. (2013), "The Emergence of Environmental Education Research," in M. Brody, J. Dillon, R. Stevenson, \& A. Wals (eds.), International Handbook of Research on Environmental Education. New York: Routledge, 13-23.

Hackell, M. (2013), "Taxpayer Citizenship and Neoliberal Hegemony in New Zealand," Journal of Political Ideologies 18(2): 129-149.

Jesson, B. (1999), Only Their Purpose Is Mad: The Money Men Take Over in New Zealand. Palmerston North: Dunmore Press.

Kahn, R. (2008), "From Education for Sustainable Development to Ecopedagogy: Sustaining Capitalism or Sustaining Life?," Green Theory and Praxis: The Journal of Ecopedagogy 4(1): 1-14.

Kopnina, H. (2012), "Education for Sustainable Development (ESD): The Turn Away from 'Environment' in Environmental Education?," Environmental Education Research 18(5): 699-717.

Kyburz-Graber, R. (2013), "Socioecological Approaches to Environmental Education and Research. A Paradigmatic Response to Behavioural Change Orientations," in R. Stevenson, M. Brody, J. Dillon, \& A. Wals (eds.), International Handbook on Envrionmental Education. New York and London: Routledge, 23-32.

Lotz-Sisitka, H., Fien, J., \& Ketholiwe, M. J. (2013), "Traditions and New Niches: An overview of Environmental Education Curriculum and Learning Research," in M. Brody, J. Dillon, R. Stevenson, \& A. Wals (eds.), International Handbook of Research on Environmental Education. New York: Routledge, 194-205.

McGuiness Institute (n.d.), Retrieved from (http://www.mcguinnessinstitute.org/ Site/Timelines/Sustainable_Development_Policy/New_Zealand_Policy_to_Date. aspx)

McKenzie, M. (2012), "Education for Y'all: Global Neoliberalism and the Case for a Politics of Scale in Sustainability Education Policy," Policy Futures in Education 10(2): 165-176.

Ministry for the Environment (1995), Environment 2010 Strategy: A Statement of the Government's Strategy on the Environment. Wellington: Learning Media.

Ministry of Education (1999), Guidelines for Environmental Education in New Zealand Schools. Wellington: Learning Media.

Ministry of Education (2007), The New Zealand Curriculum. Wellington: Learning Media.

Ministry of Education (1993), The New Zealand Curriculum Framework. Wellington: Learning Media.

Ministry of Education (2015), Te Kete Ipurangi. Retrieved from http://nzcurriculum. tki.org.nz/Curriculum-resources/Education-for-sustainability

Neilson, D. (2012), "Remaking the Connections: Marxism and the French Regulation School," Review of Radical Political Economics 44(2): 160-177.

Neilson, D. (2015), "Beyond Neoliberalism in New Zealand: An Extended Book Review," New Zealand Sociology 30(1): 199-206. 
Olssen, M., \& Peters, M. (2005), "Neoliberalism, Higher Education and the Knowledge Economy: From the Free Market to Knowledge Capitalism," Journal of Education Policy 20(3): 313-345.

Panitch, L. (1994), "Globalisation and the State," in R. Miliband and L. Panitch (eds.), The Socialist Register: Between Globalism and Nationalism. London: Merlin Press, 60-93.

Parliamentary Commissioner for the Environment (PCE) (2004), See Change: Learning and Education for Sustainability. Wellington: Parliament.

Peters, M. (2011), Neoliberalism and After? Education, Social Policy and the Crisis of Western Capitalism. New York: Peter Lang.

Plumwood, V. (2002), Environmental Culture: The Ecological Crisis of Reason. New York: Routledge.

Raco, M. (2005), "Sustainable Development, Rolled-out Neoliberalism and Sustainable Communities," Antipode 27(2): 324-347.

Robinson, W. (2001), "Social Theory and Globalization: Rise of the Transnational State," Theory and Society 30(2): 157-200.

Schubert, A., \& Lang, I. (2005), "The Literature Aftermath of the Brundtland Report 'Our Common Future.' A Scientometric Study Based on Citation in Science and Social Science Journals," Environment, Development and Sustainability 7(1): 1-8.

Selby, D. (2000), “A Darker Shade of Green: The Importance of Ecological Thinking in Global Education and School Reform," Theory into Practice 39(2): 88-96.

Statistics New Zealand (2002), Monitoring Progress Toward a Sustainable New Zealand: An Experimental Report and Analysis. Wellington.

Statistics New Zealand (2008), Statistics New Zealand's Framework for Measuring Sustainable Development. Wellington.

Statistics New Zealand (2010), Key Findings on New Zealand's Progress Using a Sustainable Development Approach. Wellington.

Suave, L. (1996), "Environmental Education and Sustainable Development: A Further Appraisal," Canadian Journal of Environmental Education 1: 7-34.

The New Zealand Government (n.d.), Resource Management Act. Wellington.

The New Zealand National Party (2012), Building a Bluegreen Future: An Environmental Policy Paper.

The United Nations Conference on Environment and Development (UNCED) (1992), Agenda 21. Rio de Janeiro: UNCED.

Tulloch, L., \& Neilson, D. (2014), "The Neoliberalisation of Sustainability," Citizenship, Social and Economics Education 13(1): 26-38.

Tulloch, L. (2013), "On Science, Ecology and Environmentalism," Policy Futures in Education 11(1): 100-114.

Williams, R. (2001), "Social Theory and Globalization: The Rise of the Transnational State," Theory and Society 30(2): 157-196.

World Commission on Environment and Development (1987), Our Common Future: Report of the World Commission on Environment and Development. Oxford: Oxford University Press. 